\title{
PENERAPAN SAK EMKM DALAM MENYUSUN LAPORAN KEUANGAN UMKM DI FOOD CITY PASAR SEGAR KOTA MAKASSAR
}

\author{
Ummu Kalsum*1, Kirana Ikhtiari ${ }^{2}$, Rismala Dwiyanti ${ }^{3}$ \\ ${ }^{123}$ Jurusan Akuntansi Fakultas Ekonomi dan Bisnis \\ Universitas Muslim Indonesia, Makassar, Indonesia \\ Email : ummukalsum.ak@umi.ac.id
}

\begin{abstract}
ABSTRAK
Penelitian ini dilakukan berdasarkan fenomena bahwa UMKM yang terdaftar di Food City Pasar Segar Kota Makassar merupakan UMKM berkembang yang sudah seharusnya menyusun laporan keuangannya berdasarkan SAK EMKM. Namun, dalam pelaksanaannya mengalami kendala dalam menyusun laporan keuangan berdasarkan SAK EMKM. Penelitian ini bertujuan untuk mengetahui dan mengkaji kendala yang dihadapi pelaku UMKM dalam menyusun laporan keuangannya berdasarkan SAK EMKM serta merancang sistem pelaporan keuangan sederhana berdasarkan SAK EMKM. Penelitian ini menggunakan pendekatan kualitatif menggunakan metode studi kasus. Sumber data yang digunakan yaitu data primer dan data sekunder. Metode pengumpulan data dilakukan dengan cara wawancara, dokumentasi dan observasi. Hasil penelitian Menunjukkan bahwa dalam penyusunan laporan keuangan, pelaku UMKM yang terdaftar di Food City Pasar segar Kota Makassar belum menerapkan SAK EMKM dikarenakan pelaku usaha tidak pernah mendapat sosialisasi, minimnya latar belakang pendidikan pelaku UMKM, tidak ada regulasi terkait pelaksanaan SAK EMKM, kurang pengetahuan dan pemahaman terkait SAK EMKM, minimnya pelatihan SAK EMKM, rendahnya modal untuk mempekerjakan staf ahli dalam menyusun laporan keuangan dan sarana prasarana yang tidak memadai serta pemilik usaha yang kurang fokus pada pelaporan hasil usahanya. Oleh karena itu, dalam penelitian ini, dirancang sistem pelaporan keuangan sederhana yang dapat membantu pelaku UMKM memahami konteks penyusunan laporan keuangan berdasarkan SAK EMKM.
\end{abstract}

Kata Kunci: Akuntansi, UMKM, Standar, Laporan

\begin{abstract}
This research was conducted based on the phenomenon that the MSMEs registered in the Food City, Fresh Market, Makassar City, are developing MSMEs that should compile their financial reports based on SAK EMKM. However, in its implementation, it encountered obstacles in preparing financial reports based on SAK EMKM. This research aims to identify and examine the obstacles faced by MSME actors in preparing their financial reports based on SAK EMKM and designing a simple financial reporting system based on SAK EMKM. This type of research is qualitative research using the case study method. The data sources used are primary data and secondary data. The data collection method was done by interview, documentation and observation. The results showed that in the preparation of financial reports, MSME actors in Food City Fresh Market Makassar City have not implemented SAK EMKM because MSME actors have never received socialization, lack of educational background for MSME actors, there are no regulations related to the implementation of SAK EMKM, lack of knowledge and understanding. related to SAK EMKM, the lack of SAK EMKM training and low capital to employ skilled staff in preparing financial reports. The conclusion of the study is that MSME actors in the food city, Pasar Segar, Makassar City have not
\end{abstract}


implemented SAK EMKM in preparing their Financial Statements and still use simple recording, namely recording cash in and cash out due to obstacles in their implementation so a simple financial reporting system is designed to help compile financial reports. based on SAK EMKM.

\section{Keyword: Accounting, UMKM, Standard, Statements.}

\section{PENDAHULUAN}

Perkembangan perekonomian Indonesia saat ini bergeser menuju arah revolusi industri 4.0. Menjawab perkembangan tersebut, Pemerintah selalu berusaha untuk meningkatkan ekonomi dan taraf hidup masyarakat, Salah satu upaya yang dilakukan adalah dengan menggalakkan program kewirausahaan melalui sektor Usaha Mikro Kecil dan Menengah (UMKM). Hal ini dikarenakan usaha kecil dan menengah memiliki isu penting dalam proses pertumbuhan ekonomi suatu bangsa secara berkelanjutan [1] dan membantu dalam hal penyerapan tenaga kerja untuk mengurangi pengangguran [2]. Peranan dan kontribusi para pelaku usaha dari skala Usaha Mikro Kecil Menengah sangatlah besar, tidak hanya dalam hal membantu penyerapan tenaga kerja yang melebihi 90\%, namun juga kontribusinya bagi Gross Domestic Product atau biasa disebut GDP Indonesia yang lebih dari 50\% [3].

Pergeseran ini menyebabkan UMKM terus beradaptasi dan bermetamorfosa untuk dapat bertahan hidup. UMKM sebagai pelaku usaha yang fleksibel dianggap mampu mengikuti perubahan tersebut sehingga sampai saat ini UMKM mampu bertahan dan memberikan dampak bagi ekonomi. Namun, kenyataannya UMKM mengalami banyak masalah dan tantangan diantaranya tentang pengelolaan dana, dimana beberapa pelaku UMKM belum bisa melakukan pembukuan dan menyusun laporan keuangan serta mengelola dananya dengan baik [4]. Dalam menjalankan aktivitas kesehariannya, UMKM tentu harus melakukan pencatatan dan pembukuan atas transaksi yang terjadi selama periode tertentu. Pencatatan tersebut akan menghasilkan laporan keuangan yang disusun berdasarkan standar akuntansi yang berlaku [5].

UMKM merupakan entitas tanpa akuntabilitas publik karena UMKM belum memiliki akuntabilitas publik signifikan dan tidak diwajibkan menerbitkan laporan keuangan untuk tujuan umum bagi pengguna eksternal. Namun, perkembangannya, kegiatan UMKM mengalami perluasan dan peningkatan yang kemudian melibatkan pihak eksternal misalnya kreditur dan supplier. Oleh karena beragamnya para 
pemakai/pengguna yang memiliki kepentingan, maka diperlukan adanya suatu standar dalam penyusunan laporan keuangan tersebut. Hal ini bertujuan untuk memudahkan para pengguna dalam memahami laporan keuangan yang dapat membantu perusahaan kecil menengah dalam menyediakan pelaporan keuangan yang relevan dan andal sehingga pihak eksternal dengan mudah mengakses informasi keuangan perusahaan [6]. Informasi akuntansi yang dihasilkan akan berguna bagi pengambilan keputusan ekonomi.

Sehubungan dengan pentingnya laporan keuangan bagi suatu entitas, maka pada tahun 2016, Dewan Standar Akuntansi Keuangan (DSAK) menerbitkan Standar Akuntansi Keuangan Entitas Mikro Kecil dan Menengah (SAK EMKM) untuk membantu pelaku UMKM dalam menyusun laporan keuangannya sehingga laporan keuangan yang dihasilkan akan menjadi lebih transparan, efisien, dan akuntabel" [7]. SAK EMKM ini efektif per 1 Januari 2018.

Pelaku usaha yang terdaftar di Food City Pasar Segar Kota Makassar sebagai wadah dan atau tempat berkumpulnya pelaku UMKM yang khusus menjalankan usaha bidang makanan dan minuman seharusnya membuat Laporan Keuangan sesuai Standar Akuntansi Keuangan Entitas Mikro Kecil dan Menengah (SAK EMKM). Namun berdasarkan pengamatan peneliti, fenomena yang terjadi, pelaku usaha yang terdaftar di Food City Pasar Segar Kota Makassar, khususnya kedai Fish n Friends dan kedai sate Taichan Uncle Katsu menyusun laporan keuangan dalam bentuk sederhana yang terdiri dari pengurangan antara pemasukan dan pengeluaran untuk mengetahui laba usaha. Kedua kedai ini melakukan pembukuan dan pencatatan secara manual berdasarkan transaksi yang terjadi sehingga laporan keuangan yang dihasilkan masih sangat sederhana. Pemilik usaha menginginkan penyusunan laporan keuangan yang sesuai sistem dan standar yang berlaku, agar usahanya dapat berkembang melalui pinjaman dari investor.

Penelitian terdahulu terkait penerapan SAK EMKM telah banyak dilakukan dan menunjukkan hasil bahwa mayoritas pelaku UMKM belum menerapkan SAK EMKM pada laporan keuangannya [8] [9] [10]. Penelitian yang dilakukan oleh Putra (2018) memberikan hasil bahwa mayoritas $(80,4 \%)$ UMKM khususnya di Kota Tangerang Selatan belum melakukan penerapan SAK EMKM pada laporan keuangannya [8]. 
Penelitian ini dilakukan dengan tujuan untuk menggali kendala-kendala yang dihadapi pelaku UMKM yang terdaftar di Food City Pasar Segar kota Makassar dalam membuat laporan keuangan berdasarkan SAK EMKM dan merancang sistem pelaporan keuangan sederhana yang sesuai dengan standar yang berlaku yang akan membantu dan memudahkan pemilik UMKM dalam menyusun laporan keuangannya sehingga laporan keuangan yang dihasilkan mampu memberikan informasi untuk pengambilan keputusan.

\section{METODE PENELITIAN}

Jenis penelitian yang digunakan dalam penelitian ini adalah kualitatif dengan menggunakan metode studi kasus. Penelitian kualitatif adalah penelitian berdasarkan pada fakta sosial dan alamiah dimana peneliti bertindak sebagai instrumen kunci, data deskriptif, tidak berdasarkan analisis statistik dan dilaporkan dalam bentuk naratif [11]. Penelitian kualitatif seringkali merujuk pada penggunaan data kualitatif (wawancara, observasi dan dokumentasi) yang diolah oleh peneliti [12].

Sumber data yang digunakan yaitu data primer dalam bentuk observasi dan wawancara serta data sekunder dalam bentuk dokumentasi. Metode pengumpulan data dilakukan dengan cara wawancara dengan pemilik UMKM dan observasi kegiatan terkait pelaporan keuangan serta telaah dokumen yang dibutuhkan misalnya catatan keuangan dan tulisan dan atau buku yang berhubungan dengan penelitian. Selanjutnya data yang diperoleh dianalisis melalui reduksi data, penyajian data, dan menarik kesimpulan.

\section{HASIL DAN PEMBAHASAN}

\subsection{Hasil}

Penelitian ini dilakukan untuk menggali kendala-kendala yang dihadapi pelaku UMKM yang terdaftar di Food City Pasar Segar kota Makassar dalam membuat laporan keuangan berdasarkan SAK EMKM dan merancang sistem pelaporan keuangan sederhana yang sesuai dengan standar yang berlaku yang akan membantu dan memudahkan pemilik UMKM dalam menyusun laporan keuangannya.

Peneliti telah melakukan observasi terhadap pemilik 55 kedai yang berada di area Food City Pasar Segar Panakkukang Kota Makassar menunjukkan hasil bahwa pelaku usaha yang terdaftar pada usaha Food City di Pasar Segar terkait informasi yang 
berkenaan dengan pengetahuan dasar akuntansi, sebanyak 91\% menjawab mereka mengetahui akuntansi terkait perhitungan uang masuk dan keluar. Sisanya 9\% menjawab tidak mengetahui, sehingga mayoritas pelaku UMKM memiliki kemampuan dasar akuntansi, namun hanya terbatas pada pengetahuan untuk pengeluaran dan pemasukan.

Terkait informasi yang berkenaan dengan pengumpulan bukti transaksi $100 \%$ menjawab mereka mengumpulkan bukti untuk setiap kegiatan uang diterima dan uang keluar dalam bentuk nota dan struk transaksi, baik secara manual ataupun secara elektronik (dalam konteks menggunakan komputer untuk menginput transaksi). Atas bukti tersebut kemudian dilakukan pencatatan, $100 \%$ menjawab mereka mencatat setiap transaksi. Namun, transaksi yang dicatat dalam buku harian yang mereka buat masih dilakukan secara sederhana yaitu terdiri dari catat uang masuk dan uang keluar. Catatan tersebut akan menjadi dasar membuat laporan yang akan memberikan gambaran keuntungan dan kerugian yang mereka dapat pada periode tertentu. Namun, laporan keuangan yang disusun masih sangat sederhana dan belum sesuai SAK EMKM.

Peneliti melakukan Telaah lebih lanjut dan wawancara dengan teknik wawancara terbuka. Dalam penelitian ini diambil dua pemilik sekaligus pengelola kedai yang bersedia untuk menjadi informan dan yang merupakan kedai dengan stan terluas dibandingkan dengan yang lain serta memiliki tingkat pengunjung yang paling padat sehingga dianggap mampu mewakili keseluruhan yaitu kedai Taichan Uncle Katsu dan Fish N Friends. Berikut kutipan wawancara dengan pemilik kedai Taichan Uncle Katsu dan Fish N Friends.

Tabel 1. Hasil Wawancara Penelitian

\begin{tabular}{|l|l|l|l|l|}
\hline No & $\begin{array}{l}\text { Pertanyaan } \\
\text { Penelitian }\end{array}$ & $\begin{array}{l}\text { Jawaban Pemilik } \\
\text { Taichan Uncle Katsu } \\
\text { (Bapak Syamsul } \\
\text { Amir) }\end{array}$ & $\begin{array}{l}\text { Jawaban Pemilik } \\
\text { Fish N Friends } \\
\text { (Ayu Nilawardana) }\end{array}$ & Telaah Peneliti \\
\hline 1 & $\begin{array}{l}\text { Apakah } \\
\text { Bapak/Ibu } \\
\text { mengetahui } \\
\text { perihal SAK } \\
\text { EMKM? }\end{array}$ & $\begin{array}{l}\text { Apa itu SAK } \\
\text { EMKM... Saya belum } \\
\text { pernah mendengarnya. }\end{array}$ & $\begin{array}{l}\text { Tidak tau, saya baru } \\
\text { kali ini dengar } \\
\text { tentang SAK } \\
\text { EMKM. }\end{array}$ & $\begin{array}{l}\text { Penyusunan } \\
\text { laporan } \\
\text { keuangan belum } \\
\text { menerapkan } \\
\text { SAK EMKM } \\
\text { dalam } \\
\text { Menyusun } \\
\text { laporan } \\
\text { keuangannya. }\end{array}$ \\
\hline
\end{tabular}




\begin{tabular}{|c|c|c|c|c|}
\hline 2 & $\begin{array}{l}\text { Bagaimana } \\
\text { mengenai } \\
\text { model } \\
\text { pencatatan } \\
\text { laporan } \\
\text { keuangan } \\
\text { perusahaan } \\
\text { yang } \\
\text { Bapak/Ibu } \\
\text { terapkan? }\end{array}$ & $\begin{array}{l}\text { Pencatatan dilakukan } \\
\text { Dengan model } \\
\text { sederhana dek seperti } \\
\text { mencatat pemasukan } \\
\text { total, pengeluaran dan } \\
\text { pemasukan bersih saja } \\
\text { karena kami tidak } \\
\text { memiliki juru keuangan } \\
\text { tersendiri. Dengan kata } \\
\text { lain, segala keuangan } \\
\text { hanya kami yang } \\
\text { mengelolanya. }\end{array}$ & $\begin{array}{l}\text { Masih pakai buku } \\
\text { menggunakan jurnal } \\
\text { masuk dan keluar. }\end{array}$ & $\begin{array}{l}\text { Pencatatan } \\
\text { masih sangat } \\
\text { sederhana dan } \\
\text { belum } \\
\text { memenuhi } \\
\text { kaidah SAK } \\
\text { EMKM serta } \\
\text { tidak berdasar } \\
\text { pada siklus } \\
\text { akuntansi. }\end{array}$ \\
\hline 3 & $\begin{array}{l}\text { Bagaimana } \\
\text { cara } \\
\text { Bapak/Ibu } \\
\text { mengetahui } \\
\text { keuntungan } \\
\text { atau } \\
\text { kerugian } \\
\text { yang terjadi? }\end{array}$ & $\begin{array}{l}\text { Kami hanya mencatat } \\
\text { pemasukan total, } \\
\text { pengeluaran dan } \\
\text { pemasukan bersih saja, } \\
\text { selisih dari itu yang } \\
\text { kami lihat. }\end{array}$ & $\begin{array}{l}\text { Masih pakai buku } \\
\text { menggunakan jurnal } \\
\text { masuk dan keluar. } \\
\text { Tapi penting, agar } \\
\text { kita tau kalau } \\
\text { misalnya ada yang } \\
\text { kurang itu karena } \\
\text { apa, mungkin } \\
\text { pengeluaran dua kali } \\
\text { seperti makanan } \\
\text { pencatatan kita } \\
\text { kurang misalnya } \\
\text { pencatatannya } \\
\text { sepuluh tapi yang } \\
\text { keluar sebelas. }\end{array}$ & $\begin{array}{l}\text { Laba-Rugi yang } \\
\text { dihasilkan } \\
\text { belum } \\
\text { mencerminkan } \\
\text { laba rugi yang } \\
\text { sebenarnya } \\
\text { (belum sesuai } \\
\text { SAK EMKM) }\end{array}$ \\
\hline 4 & $\begin{array}{l}\text { Apakah ke } \\
\text { depan } \\
\text { Bapak/Ibu } \\
\text { akan } \\
\text { menerapkan } \\
\text { pelaporan } \\
\text { keuangan } \\
\text { yang seperti } \\
\text { apa? }\end{array}$ & $\begin{array}{l}\text { Setelah mendengar } \\
\text { SAK EMKM dari adik } \\
\text { untuk standar } \\
\text { pelaporan, maka tentu } \\
\text { harus mengacu pada } \\
\text { standar tersebut. }\end{array}$ & $\begin{array}{l}\text { Seharusnya ada } \\
\text { standar yang } \\
\text { digunakan... Setelah } \\
\text { mendengar SAK } \\
\text { EMKM sebagai } \\
\text { standar pelaporan, } \\
\text { maka sudah harus } \\
\text { untuk membuat } \\
\text { laporan keuangan } \\
\text { berdasar itu, hanya } \\
\text { masih perlu belajar } \\
\text { dan pendampingan. }\end{array}$ & $\begin{array}{l}\text { Pelaku UMKM } \\
\text { ingin } \\
\text { menerapkan } \\
\text { SAK EMKM } \\
\text { dalam } \\
\text { pelaporannya } \\
\text { namun } \\
\text { dibutuhkan } \\
\text { sosialisasi dan } \\
\text { pendampingan. }\end{array}$ \\
\hline
\end{tabular}

Sumber: Data Wawancara diolah peneliti, 2020

Pelaku UMKM masih menggunakan sistem pencatatan sederhana sesuai dengan pengetahuan pemilik usaha yaitu hanya sekedar mencatat kas masuk dan kas keluar. Mereka tidak mengetahui SAK EMKM sehingga tidak menerapkan SAK tersebut dalam aktivitas keuangannya. Mereka sama sekali tidak melakukan penjurnalan ataupun 
buku besar dalam pencatatannya. Pencatatan yang dilakukan oleh kedua pengelola kedai masih sangat sederhana, selain itu pencatatan yang mereka lakukan hanya berdasarkan pemahaman mereka.

\subsection{Pembahasan}

Akuntansi Berbasis Standar Akuntansi Keuangan Entitas Mikro Kecil dan Menengah (SAK EMKM) adalah standar akuntansi yang dibuat khusus untuk usaha-usaha berskala mikro, kecil dan menengah dalam pembuatan Laporan Keuangan mereka. SAK EMKM efektif diterapkan di Indonesia per 1 Januari 2018.

Pelaku UMKM yang terdaftar di Food City Pasar Segar Makassar belum menyusun laporan keuangan mereka berdasarkan SAK EMKM, mereka sangat menyadari bahwa sangat penting untuk melakukan penyusunan laporan keuangan dan perkembangan usaha. Penerapan SAK EMKM dalam menjalankan proses akuntansi dan menyusun laporan keuangan menjadi hal yang wajib untuk dilaksanakan bagi pelaku UMKM sebagai suatu aturan atau regulasi yang harus ditaati. Namun, kenyataannya di lapangan, khususnya pelaku UMKM yang terdaftar di Food City Pasar Segar Makassar belum menerapkannya. Banyak alasan yang menjadi faktor penyebab dan kendala dalam penerapannya, diantaranya:

1. Tidak ada sosialisasi dari instansi terkait. Pelatihan dari pihak pemerintah maupun lembaga yang membawahi UMKM masih kurang maksimal, sehingga pemahaman akan pentingnya SAK EMKM masih belum dipahami pelaku UMKM [13]. Dalam hal ini yang dimaksudkan adalah otoritas yang mengeluarkan peraturan yaitu IAI (Ikatan Akuntan Indonesia) dan mengawasi pelaku UMKM yakni Dinas Koperasi dan UMKM Kota Makassar.

2. Latar Belakang Pendidikan. Selama ini pemahaman bentuk pencatatan keuangan yang dilakukan sesuai dengan pengetahuan dan pemahaman yang dimiliki. Pelaku UMKM belum sadar akan pentingnya laporan keuangan di suatu perusahaan karena keterbatasan informasi dan pengetahuan tentang akuntansi sangat terbatas. Hal seperti ini berkaitan dengan latar belakang pendidikan para Sumber Daya Manusia (SDM) di UMKM tersebut [10].

3. Belum adanya regulasi yang mewajibkan secara formal terkait penerapan SAK EMKM dalam pelaporan keuangan. Pemilik kedai selaku pelaku UMKM tidak 
melakukan pencatatan akuntansi berbasis SAK EMKM karena tidak adanya pengawasan dari pihak-pihak yang terkait, tidak adanya audit atas laporan keuangan, dan kurangnya sumber [14].

4. Kurangnya pengetahuan oleh pemilik UMKM mengenai SAK EMKM dalam penyusunan laporan keuangan. Kendala kesiapan UMKM dalam mengimplementasikan SAK EMKM adalah kesadaran akan pentingnya laporan keuangan belum dimiliki oleh pelaku UMKM serta pengetahuan tentang SAK EMKM yang dimiliki masih minim [15].

5. Minimnya Pelatihan yang diikuti. Pelaku UMKM berpendapat bahwa pelatihan akuntansi yang disediakan tidak mengatasi tantangan langsung sehari-hari yang dihadapi oleh para UMKM sehingga bukan kebutuhan yang diprioritaskan [16]. sehingga mereka juga bisa dikatakan tidak termotivasi untuk mengikuti pelatihan tersebut dan akhirnya mereka belum menerapkan SAK EMKM.

6. Modal yang tidak memadai, menyediakan tenaga ahli yang khusus untuk menyusun laporan keuangan terutama berdasar pada aturan tentu membutuhkan modal yang besar untuk membayar mereka.

7. Ketersediaan sarana dan prasarana yang digunakan untuk Menyusun laporan keuangan, misalnya pengadaan alat teknologi informasi untuk membantu mereka Menyusun laporan keuangan.

8. Fokus pemilik yang tidak berorientasi pada pelaporan keuangan melainkan hanya berfokus pada upaya penerimaan perusahaan sehingga cenderung mengabaikan penggunaan sistem pelaporan keuangan

SAK EMKM ini merupakan salah satu dorongan kepada pengusaha-pengusaha di Indonesia agar dapat berkontribusi secara signifikan dalam pengembangan UMKM yang lebih maju. Diharapkan dengan adanya SAK EMKM para pelaku UMKM mampu membuat laporan keuangannya sendiri dan memudahkan dalam melihat bagaimana keuangan usahanya. Pelaku usaha yang terdaftar di Food City Kota Makassar berkeinginan dan termotivasi untuk menyusun laporan keuangannya berdasarkan standar yang berlaku yaitu SAK EMKM sebagai wujud ketaatan pada aturan yang berlaku dan usaha untuk meningkatkan kinerja perusahaan.

Berangkat dari kendala yang dihadapi oleh pelaku UMKM dan untuk menjawab tujuan penelitian ini, peneliti merancang sistem pelaporan keuangan sederhana yang 
dapat diterapkan oleh pelaku UMKM yang terdaftar di Food City Pasar Segar Kota Makassar sebagai berikut:

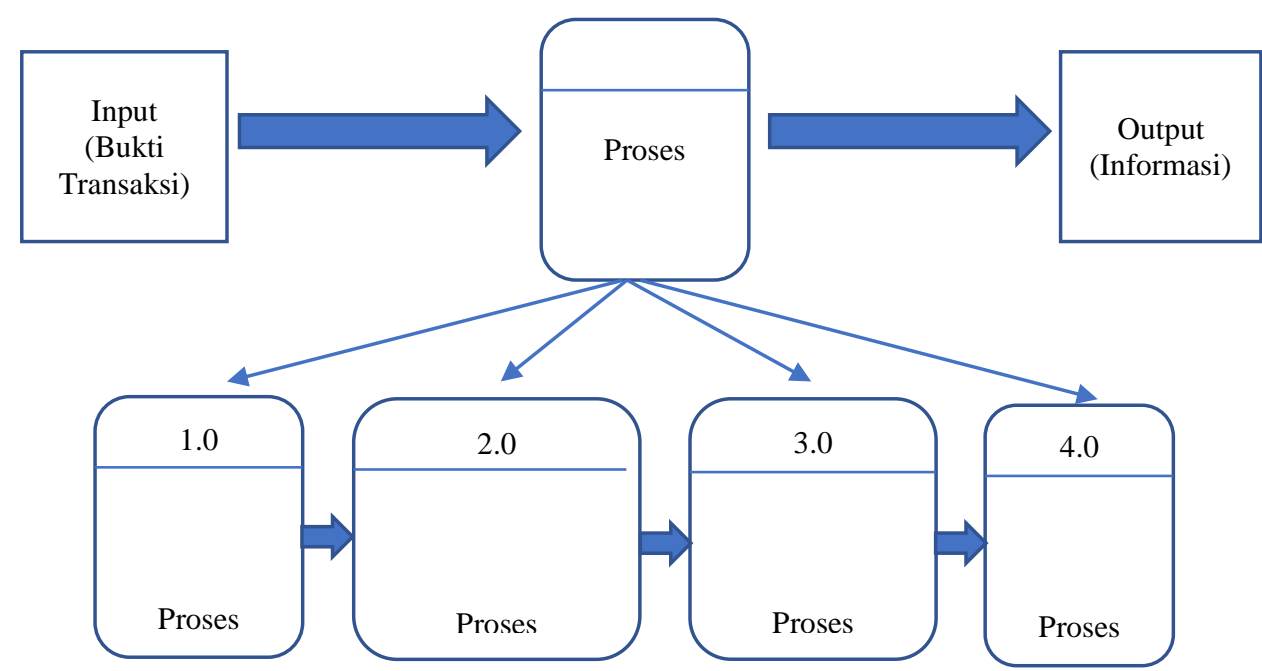

Gambar.1 Sistem Pelaporan Keuangan Sederhana

Sistem informasi pencatatan dan pelaporan akuntansi dimulai dengan melakukan input bukti transaksi yang berupa faktur, nota, kuitansi, struk dan bukti keuangan lainnya ke proses 1.0 yaitu pencatatan yang dilakukan secara periodik ke dalam buku harian (jurnal). Proses selanjutnya, 2.0 yaitu pengklasifikasian kedalam buku besar berdasarkan akunnya. Proses 3.0 merupakan proses ikhtisar ke neraca saldo yang kemudian akan dibuatkan kertas kerja untuk membantu menyusun laporan keuangan. Proses 4.0 yaitu pelaporan keuangan yang didasarkan pada SAK EMKM dimana laporan keuangan terdiri dari laporan posisi keuangan, laporan laba rugi dan catatan atas laporan keuangan. Penerapan sistem pelaporan akuntansi sederhana ini menjadi dasar bagi pelaku UMKM di Food City Kota Makassar untuk Menyusun laporan keuangannya sesuai dengan standar yang berlaku yaitu SAK EMKM.

\section{KESIMPULAN}

Kesimpulan dalam penelitian ini bahwa pelaku UMKM yang terdaftar di Food City Pasar Segar Kota Makassar dalam menyusun laporan keuangannya belum menerapkan SAK EMKM dikarenakan kendala-kendala yang dihadapi yaitu tidak ada sosialisasi dari instansi terkait, latar belakang pendidikan, tidak ada regulasi terkait kewajiban penerapan SAK EMKM, kurangnya pengetahuan pemilik UMKM, minimnya pelatihan, 
modal dan sarana prasarana yang tidak memadai serta pemilik usaha yang kurang fokus pada pelaporan hasil usahanya. Oleh karena itu, dirancang sistem pelaporan akuntansi sederhana yang dapat membantu pelaku UMKM memahami konteks penyusunan laporan keuangan berdasarkan SAK EMKM.

\section{SARAN}

Diharapkan bagi UMKM yang ada di Food City Pasar Segar Kota Makassar untuk menyelenggarakan akuntansinya mulai dari pencatatan sampai pada penyusunan laporan keuangan yang berdasarkan pada SAK EMKM. Selain itu sebaiknya pelaku UMKM di Food City pasar Segar Kota Makassar harus rutin dan aktif untuk mencari dan mengakses informasi terkait aturan dalam membuat laporan keuangan.

Selain bagi UMKM, bagi standard setter dalam hal ini Ikatan Akuntan Indonesia hendaknya lebih gencar melakukan sosialisasi untuk meningkatkan pemahaman dan pengetahuan pelaku UMKM terhadap SAK EMKM. Pelaku usaha hendaknya menggunakan sistem pencatatan dan pelaporan keuangan yang menggunakan komputerisasi seperti zahir dan myob. Bagi peneliti selanjutnya diharapkan melakukan kajian mendalam terkait sistem pencatatan dan pelaporan keuangan yang sistematis yang terintegrasi dengan tools untuk menyusun laporan keuangan.

\section{DAFTAR}

[1] A. Nuvitasari, N. C. Y dan N. Martiana, Implementasi SAK EMKM Sebagai Dasar Penyusunan Laporan Keuangan Usaha Mikro Kecil dan Menengah (UMKM), International Journal of Social Science and Business, vol. 3, no. 3, pp. 341-347, 2019.

[2] A. Prajanto dan I. Septriana, "Implementasi Penerapan SAK EMKM serta Dampaknya pada Kualitas Pelaporan Keuangan UMKM (Studi Kasus Pada UMKM Se Kota Semarang),” Aset, vol. 20, no. 2, pp. 79-89, 2018.

[3] Kementerian Koperasi dan UKM RI, "Perkembangan Data Usaha Mikro, Kecil, Menengah (UMKM) Dan Usaha Besar (UB) Tahun 2016 - 2017,” Desember 2017. [Online]. 
[Diakses Mei 2020].

[4] Y. Setyawati dan S. Hermawan, "Persepsi Pemilik Dan Pengetahuan Akuntansi Pelaku Usaha Mikro Kecil Dan Menengah (UMKM) Atas Penyusunan Laporan Keuangan," Riset Akuntansi dan Keuangan Indonesia, vol. 3, no. 2, pp. 161-204, 2018.

[5] M. O. Uno, L. Kalangi dan R. J. Pusung, "Analisis Penerapan Standar Akuntansi Keuangan Entitas Mikro, Kecil, Dan Menengah (Sak Emkm) Pada Usaha Mikro, Kecil, Dan Menengah (Studi Kasus Pada Rumah Karawo Di Kota Gorontalo), Jurnal EMBA, vol. 7 , no. 3, pp. 3877 - 3898, 2019.

[6] T. Amani, "Penerapan SAK-EMKM Sebagai Dasar Penyusunan Laporan Keuangan UMKM (Studi Kasus di UD Dua Putri Solehah Probolinggo)," Assets, vol. 2, no. 2, pp. 12-20, 2018.

[7] Ikatan Akuntan Indonesia (IAI), "Exposure Draft SAK EMKM," 23 September 2016. [Online]. Available: http://iaiglobal.or.id/v03/files/draft_ed_sak_emkm_kompilasi.pdf. [Diakses 25 Mei 2020].

[8] . Y. M. i Putra , "Pemetaan Penerapan Standar Akuntansi Keuangan EMKM pada UMKM Di Kota Tangerang Selatan," Profita: Komunikasi Ilmiah Akuntansi dan Perpajakan, vol. 11, no. 2, pp. 2622-1950, 2018.

[9] M. A. Purba, "Analisis Penerapan Sak Emkmpada Penyusunan Laporan Keuangan UMKM Di Kota Batam,” JURNAL AKUNTANSI BARELANG, vol. 3, no. 3, pp. 55-63, 2019.

[10] R. A. Mutiah , "Penerapan Penyusunan Laporan Keuangan pada UMKM Berbasis SAK EMKM," International Journal of Social Science and Business., vol. 3, no. 3, pp. 223-229, 2019.

[11] S. Hermawan dan A. Amirullah, Metode Penelitian Bisnis Pendekatan Kuantitatif dan Kualitatif, Malang: Media Nusa Creative, Malang. ISBN 978-602-6931-38-2, 2016.

[12] A. Kamayanti, Metodologi Penelitian Kualitatif Akuntansi, Malang: Penerbit Peneleh, 2020.

[13] N. Salmiah dan S. T. N. I. Adino , "Pemahaman Pelaku Umkm Terhadap SAK EMKM : Survey pada UMKM yang Terdaftar Di Dinas Koperasi Dan UKM Kota 
Pekanbaru," Akuntansi Dewantara, vol. 2, no. 2, pp. 194-204, 2018.

[14] A. Chakraborty, "Impact of Poor Accounting Practices on the Growth and Sustainability of SMEs. Vol 3, Issue 5, pp. 227-231.," The International Journal Of Business \& Management., vol. 3, no. 5, pp. 227-231, 2015.

[15] A. Sholikin dan A. Setiawan, "Kesiapan UMKM terhadap Implementasi SAK EMKM (Studi UMKM di Kabupaten Blora) 35-50.," Journal of Islamic Financial an Accounting, vol. 1, no. 2, pp. 35-50, 2018.

[16] R. S. Hanifati dan L. Leo, "Upaya Meningkatkan Implementasi SAK EMKM melalui Peran Akuntan Berpraktik," Jurnal Pendidikan Akuntansi dan Keuangan , vol. 7, no. 7, pp. 65-80, 2019 . 